
\title{
28 Research Suare \\ Manufacturing of Bricks From Coal Mine Overburden Dump of Korba, Chhattisgarh, India
}

Shailendra Kumar Singh ( $\sim$ mr.shiloo11@gmail.com )

Natural Resources and Environment Management and Fellow, AcSIR, CSIR-CIMFR, Barwa https://orcid.org/0000-0002-8988-3932

\section{Ranjeet K Singh}

Central Institute of Mining and Fuel Research CSIR

Research

Keywords: Mixing coal mine overburden, sodium silicate and Ordinary Portland Cement (OPC), Indian standard (IS)

Posted Date: December 7th, 2020

DOI: https://doi.org/10.21203/rs.3.rs-120527/v1

License: @ (i) This work is licensed under a Creative Commons Attribution 4.0 International License. Read Full License 


\section{Abstract}

Mixing coal mine overburden with sodium silicate and cement, for manufacturing bricks was studied with the objective of converting the coal mine overburden waste into value-added products. Bricks were prepared using different compositions of coal mine overburden with proportions of sodium silicate and Ordinary Portland Cement (OPC), in cuboid mould (9" X 5"X 3"). Bricks were air dried for 24 hours, placed in oven for $115 \pm 10^{\circ} \mathrm{C}$ for 24 hours. Characterization of tailings and manufactured bricks were done. Mechanical properties such as compressive strength (CS), water absorption (WA), loss on ignition (Lol) and efflorescence were measured. The maximum CS of $9.5 \mathrm{~N} / \mathrm{mm}^{2}$ was recorded for brick having overburden to cement ratio of 8:2. However, for making it more economical the ratio of 9:1 was considered and this compares very well cost with full filed the Indian standard (IS): 3495 (Part 1) (1992) of bricks. The results also indicated that the overburden percentage in the bricks affect their mechanical properties. The WA rates of the manufactured bricks are low compared to standard conventional clay bricks, and the same varies with process parameters. The low capillary pore may deter the formation of efflorescence. The process, with standardized parameters, may be commercially adapted, and large quantities of coal mine overburden may be put to use in making bricks. Thus, the process technology observed in this paper can potentially convert the huge amount of environmentally hazardous waste into value added product. Coal mine overburden may materialize as a sustainable supplement to conventional clay, use of which in brick making is totally restricted. The finding also usher a new area of research.

\section{Introduction}

Globally, China is the largest producer of coal followed by India. (https://www.power-technology.com). In 2018, worldwide coal production stood at 7813.3 million tons with India contributing around 771 million tons (https://www.worldcoal.org). In India the bulk (around 90\%) of coal extraction takes place through open cast mining method, (ICOMS 2019) and the remaining 10\% is contributed by underground mining. Opencast mining generates a large volume of waste rock and this overlying rock is heaped in the form of overburden (OB) dumps (Gupta et al. 2015), generally, the striping ratios of Indian coal mines is 2.2 (https://coal.nic.in) and it may vary from site to site.

Modern development mostly depends on the mining industry for the supply of raw materials to industry (Tripathi et al. 2016). Due to mining activities, OB has generated and it's stored to occupy a large amount of land, which lost its originality and it also creates an ecological disturbance (Singh et al. 2018) i.e. quality of soil degraded (Barpanda et al., 2001). These dump materials are normally generated, fine particles from it become highly prone to blowing by the wind. These get spread over the surrounding on the fertile land, plant; disturb their natural quality and growth of fresh leaves. It has been found that OB dump top materials are usually deficient in major nutrients. Hence, most of the OB dumps do not support plantation (Yaseen et al. 2012). Therefore, there is an urgent need to establish an alternative use of these wastes for protecting and preserving the environment. Solidification/stabilization considered potential long-term solutions and an attractive alternative for the remediation and disposal of improperly discarded hazardous waste as the solidification of waste material to reduce the risk of environmental pollution and also helped in the conservation of natural resources (Sharma and Joshi 2015). 
Bricks are one of the demanding building materials in the world and all over the world for manufacturing largely depend on the clay materials and the source of the clay materials are also going to lose due to the utilization of topsoil. Whereas some countries have banned the use of normal clay bricks and had advocated for the use of solid wastes for manufacturing building materials to phase-out common clay solid brick (Chen et al. 2011; Tripathi et al. 2017). India also banned the fire clay brick/red bricks in Notification dated 27th February 2019 -G.S.R. 157 (E) and encouraging the use of alternative materials. The use of industrial waste can address some of the issues faced by infrastructure and development industries as well as find great means of waste disposal (Hossiney et al. 2018). Several countries, as well as India, had started to utilize mine waste for bricks and block manufacturing (Harrison et al. 2002, Jamal and Sidharth 2008). In India also start to utilized the coal OB red mud, iron, and copper tailing and marble slurry, granite cutting waste as a building material (Jamal and Sidharth 2008; Pandey and Agrawal 2002; Reddy 2004; Reddy et al. 2003, Singh et al. 2016, Bhaskar et al. 2014, Rana et al. 2015) lime-slag with sand (Malhotra and Tehri 1996), copper tailings (Morchhale et al. 2006) were also found suitable as building materials.

Jamal and Sidharth (2008), developed bricks from coal overburden with fly ash and other rock. A mixture of crushed overburden with water was prepared and kept for 8-10 hours for proper mixing and soaking of water then, mixture filled in the wood mold. Mold is overturned and kept for sun-dried for 6-8 days. Then, bricks were kiln at $800-1200^{\circ} \mathrm{C}$, allowed to cool for 2 days. Luo et al. (2020), making bricks by mixing iron ore tailing and coal gangue powder with a binder such as sewage sludge and shale in different ratios. There were a number of researchers involved to study different waste utilizing including coal mine $\mathrm{OB}$ to bricks manufacturing. They were cited need high temperature, kiln firing, and different size either in cubic size or smaller in size with a binder such as fly ash, sodium silicate, $\mathrm{NaOH}$ and cement but manufacturing of bricks from coal mine overburden with cement and sodium silicate (SS) were no one utilize. The system discussed has complex and time-consuming manufacturing processes and cube and small size comparatively present study.

Coal mine $\mathrm{OB}$ mainly constitutes a large volume of inorganic substances with an extent of friable sandstone, shale, and fired clay and in less amount of conglomerate at some coal mines areas. The major mineral constituents are quartz, cementing material and a minor amount of feldspar, Mica and a few grains of heavy minerals are also present (Jamal and Sidharth 2008). Due to similar ingredients of the clay coal mine, OB may be used as a substitute for clay for producing bricks and reduce ecological disturbance along with sustainability in the environment.

The aim of this study was to investigate the substitute of clay materials for bricks manufacturing to using the coal mine overburden. It is not only become the substitution but also it reduces the pollution load on environment to minimizing the dust and leachate emission thorough the utilization of coal mine OB waste.

\section{Materials And Methods}

\section{Raw materials}

The $\mathrm{OB}$ sample was taken from Manikpur open cast project (OCP) mine and its falls between latitudes $22^{\circ} 19^{\prime} 00^{\prime \prime} \mathrm{N}$ to $22^{\circ} 19^{\prime} 30^{\prime \prime} \mathrm{N}$, and longitudes $84^{\circ} 42^{\prime} 30^{\prime \prime} \mathrm{E}$ to $82^{\circ} 44^{\prime} 30^{\prime \prime} \mathrm{E}$ (Figure. 1). This study site is located south-eastern part of Korba coalfield Chattisgarh, India, and the terrain of the area is a flattened plain with 
local steep approaches to the streams and nallahs in the northern eastern plain. This coal mine is acquired from south eastern coalfield Limited (SECL) and it is a Miniratna company. The stripping ratio of Manikpur OCP is $2.68 \mathrm{~m}^{3} / \mathrm{t}$ (http://environmentclearance.nic.in). For the binding of the bricks, the sodium silicate (SS) and Cement $(\mathrm{C})$ had used and there were bought from the local shops of Dhanbad township of Jharkhand, India. The tap water was used in curing and casting the bricks and its $\mathrm{pH}$ values varied from 6.5 to 8.5 . The grain size distribution or texture of the coal mine OB was done though the sieve analysis following the proposed protocol of Mishra (1968) using sieve type $4.750 \mathrm{~mm}, 2.00 \mathrm{~mm}, 0.425 \mathrm{~mm}$, and $0.075 \mathrm{~mm}$. Specific gravity (SG) was determined through flowing Bureau of Indian standard (IS: 1122-1974), Reaffirmed 2003 whereas bulk density (BD) was determined to following the method prescribed in TSBF Handbook (Anderson and Ingram 1992). The fineness modulus (FM) was determined according to ASTMC 125 is designed by adding the cumulative percentage by mass retained on each of a specified series of sieves and divided by 100 (http://www.ce.memphis.edu). The soil moisture content was measured by the gravimetric method and Porosity (\%) following the procedure prescribed by Gupta (2004).

\section{Preparation of brick samples}

The flow chart of the bricks manufacturing process shown in Figure 2. The ingredients were crushed through roller crusher then sieved before using in brick making so it was helpful to blend raw material easily. Cement used in this mix was ordinary Portland cement (OCP). The dry mixtures with different proportions were firstly mixed to homogenize for $10 \mathrm{~min}$, then approximately $30 \%$ water of mixture weight was added to it and for 10 min it was mixed to make a homogenous paste. The moistened granules were cast in wood mold (size 223 $\mathrm{mm} \times 100 \mathrm{~mm} \times 75 \mathrm{~mm}$ ) and compacted using a vibrating table. The formed specimen was air-dried in at room temperature for 8 hours and desiccated specimen kept in an oven at $115 \pm 10{ }^{\circ} \mathrm{C}$ for curing for 24 hours. As required by the concrete common brick standard for construction bricks, the important properties of bricks including compressive strength (CS), water absorption (WA), and efflorescence (EFF) were analysed to determine the suitable condition for developed qualified bricks. The CS of specimens was measured by the universal testing machine (UTM). WA through Archimedes method in deionized water (Vakalova and Revva 2020) and EFF tested were performed in accordance with the method described in (Indian Standard (IS): 3495 (Part 1, part 2 and part 3), 1992) respectively. The chemical composition of OB material was determined by Xray fluorescence (XRF) (Panalytical Magi X PW 2424). The microstructure of the bricks was analysed through the scanning electron microscope (SEM) (MERLIN VP Compact, ZEISS). The intrinsic mixture proportions of different used materials were divided into two groups i) OB with SS ratio (09:01 (A1),17:03 (A2) and 08:02 (A3)) and ii) OB with OPC ratio (09:01 (B1), 17:03 (B2) and 08:02 (B3)). Both of the groups reflected to have almost a nil crack to be related on a united basis. Due to the higher WA and angular shape of iron tailing compared to ordinary collections, extra water was added to keep the workability constant.

\section{Results And Discussion}

\section{Physical properties of raw materials}

Sieve analysis tests of the OB shown that particle passing $4.75 \mathrm{~mm}$ IS sieve and retained on $0.075 \mathrm{~mm}$ IS sieve was coarse sand to fine sand. The fine generated was presented in Table 1. Particle size also plays a very vital role in bricks manufacturing because it acts as a moulding capability of the materials. Texture helps 
the movement of air and water holding capacity rate, which can enter and move through soil (FAO 2020). According to the VSBK program (2008), soil helped in the moulding of soil into bricks therefore this study has coarse sand to fine sand recorded in heavy amount whereas silt and clay in very low amount then its help to manufacturing good or high-quality bricks. According to Rathore et al. (2020) a high proportion of clay results in cracking of bricks due to excessive shrinkage.

The values for SG, BD (g/cm3), porosity (\%), FM and MC (\%) were 2.22, 2.81, 25, 2.79, and 7.01 respectively (Table 2). According to Rathore et al. (2020), the role of the SG was the mass decider of the bricks made from it and it totally depends on the particle size, texture void ratios, moisture content, and mineral compositions (Adyel et al. 2012.). The typical soil has usually 2.65 to 2.85 of SG, and he was also stated that the iron-rich soil has a larger SG than silica (Bowels 2012). Therefore, the bricks making through clay having higher SG than their weight was high, due to lower SG clay was preferred for clay bricks manufacturing. In this study, the value of SG is lower than the ranged prescribed by the Bureau of Indian standard, hence this OB material is suitable for bricks making.

\section{Mineralogical composition raw materials}

The X-Ray Diffraction (XRD) patterns of the coal mine OB shown in Fig. 3. It's clearly reveals that the quartz $(60.897 \%)$, microcline intermediate $2(18.441 \%)$ and kaolinite $(17.024 \%)$ are the major phase while muscovite $2 \mathrm{M} 1(1.883 \%)$ and calcite $(1.755 \%)$ are the minor minerals phase.

\section{Chemical properties of raw materials}

The chemical composition of raw materials was shown in Table 3. The coal mine OB contains the oxides form of $\mathrm{SiO}_{2} 58.86 \%, \mathrm{Al}_{2} \mathrm{O}_{3} 29.90 \%, \mathrm{Fe}_{2} \mathrm{O}_{3} 4.17 \%, \mathrm{CaO} 1.21 \%, \mathrm{MgO} 0.81 \%, \mathrm{TiO}_{2} 1.76 \%, \mathrm{~K}_{2} \mathrm{O} 3.44 \%, \mathrm{Na}_{2} \mathrm{O} 0.11 \%$, $\mathrm{P}_{2} \mathrm{O}_{5} 0.08$, and $\mathrm{SO}_{3} 0.47 \%$ (Table 3 ) whereas OPC were used for study and its chemical composition with the higher composition of $\mathrm{CaO} 61.24 \%, \mathrm{SiO}_{2} 24.98 \%, \mathrm{Al}_{2} \mathrm{O}_{3} 4.84 \%, \mathrm{Fe}_{2} \mathrm{O}_{3} 3.02 \%, \mathrm{MgO} 1.42 \%, \mathrm{TiO}_{2} 0.48 \%, \mathrm{~K}_{2} \mathrm{O}$ $0.39 \%, \mathrm{Na}_{2} \mathrm{O} 0.29 \%, \mathrm{P}_{2} \mathrm{O}_{5} 0.8$, and $\mathrm{SO}_{3} 2.5 \%$ (Table 3 ). The chemical constituent (\%) of sodium silicate (SS) was silica $\left(\mathrm{SiO}_{2}\right)$, sodium oxide $\left(\mathrm{Na}_{2} \mathrm{O}\right)$, total solid and water content were $34.78,16.22,51$ and 49 respectively whereas $\mathrm{Na}_{2} \mathrm{O}: \mathrm{SiO}_{2}$, was 1: 2.14 .

The constituent of the raw material when compared to the $\mathrm{FCB}$, the content of the oxides form of $\mathrm{Al}_{2} \mathrm{O}_{3}$ was high but the content of $\mathrm{Fe}_{2} \mathrm{O}_{3}$ and $\mathrm{CaO}$ were low. The content of $\mathrm{SiO}_{2}, \mathrm{Al}_{2} \mathrm{O}_{3}$ in soil samples ranged between 50 to $60 \%, 20$ to $30 \%$ respectively, whereas $\mathrm{CaO}$ and $\mathrm{Fe}_{2} \mathrm{O}_{3}$ were not exceeded than $10 \%$ (Velasco et al. 2014). In this study $\mathrm{SiO}_{2}, \mathrm{Al}_{2} \mathrm{O}_{3}$ were $58.86 \%$ and $29.30 \%$ respectively and $\mathrm{CaO}$ and $\mathrm{Fe}_{2} \mathrm{O}_{3}$ were 1.21 and 4.17 respectively then it represents partially similar properties for brick manufacturing. According to Pinheiro et al. (2008) and White et al. (2015) silicon oxide $\left(\mathrm{SiO}_{2}\right)$ content was higher than $50 \%$ was a strong indicator of the presence of free silica and clay minerals such as kaolinite $\left(\mathrm{Al}_{2} \mathrm{O}_{3} \cdot 2 \mathrm{SiO}_{2} \cdot 2 \mathrm{H}_{2} \mathrm{O}\right)$, similarly in this study silicate proportion in $\mathrm{OB}$ was 58.86 \% then it indicates kaolinite presence. The large amount of $\mathrm{SiO}_{2}$ in coal mine $\mathrm{OB}$ may impart greater strength (Behra et al. 2020).

The limit of $\mathrm{CaO}$ in clay content ranged up to $10 \%$ which was low in $\mathrm{OB}$ samples. Consequently, to overcome this cement is added while the preparation of bricks (Velasco et al. 2014). OPC can better hydrate and stabilize 
when in contact with water as well as maintaining and developing its strength (Lv et al. 2015; Du et al. 2019). $\mathrm{SiO}_{2}$ and $\mathrm{Al}_{2} \mathrm{O}_{3}$ contributed more than $50 \%$ by weight which helps in making good bricks, as particles react with cement and form cementitious gels of silicate and aluminate (Zhou et al. 2012) in this study contribution of $\mathrm{SiO}_{2}$ and $\mathrm{Al}_{2} \mathrm{O}_{3}$ were more than $50 \%$ then its indication of making good bricks. $\mathrm{Al}_{2} \mathrm{O}_{3}$ was high it leads to higher mechanical strength in the brick but the presence of $\mathrm{Fe}_{2} \mathrm{O}_{3}$ can cause the problem of effloresces therefore it ranges was recommended $10 \%$ (Velasco et al. 2014). The loss on ignition of coal mine OB was which was due to the removal of hydrate presence in $\mathrm{OB}$ and the un-burnt form of carbon in it. The limit for loss on ignition was $12 \%$ as a greater amount of organic matter will interfere in bricks (Webb 1994).

\section{Mineralogical composition manufactured brick}

The X-Ray Diffraction (XRD) patterns of the manufactured bricks of coal mine OB with cement shown in Fig. 4. It's reveals that kaolinite $(32.046 \%)$, quartz $(27.108 \%)$, microcline intermediate $(13.651 \%)$ calcite $(9.569 \%)$ and vaterite $(7.916 \%)$, were major mineral composition and whereas minor mineral composition was muscovite $2 \mathrm{M} 1(4.400 \%)$, hematite $(2.376 \%)$, anatase $(2.060 \%)$, and periclase $(0.874 \%)$.

\section{Mechanical properties of manufactured brick}

\section{Compressive strength (CS)}

The CS of the brick specimen was shown in Table 4 and it plays a vital role in the application of bricks in construction or building materials. According to the FCB standard (IS: 3495-(Part1), (1992), the minimum CS required is $3.5 \mathrm{~N} / \mathrm{mm}^{2}$.

This study indicated that the maximum CS was $9.5 \mathrm{~N} / \mathrm{mm}^{2}$ in specimen $\mathrm{B} 3$ in ratios (OB: $\mathrm{C}, 08: 02$,) and minimum in $4.2 \mathrm{~N} / \mathrm{mm}^{2}$ in $\mathrm{A} 1$ (OB: SS, 09:01) (Table 4). The CS increased with an increase in OPC and sodium silicate content in Table 4. The highest CS was observed at $20 \%$ addition of OPC with OB. According to Islam et al. (2014), cement is responsible for the development of strength. The cement helps for a long-term build-up of strength (Nagaraj et al. 2014). It is postulated that if the silica percent is more than $17-25 \%$ then the strength increases further. The maximum amount of silica and alumina extends the setting time of the OPC during the formation of brick (Raj 2017).

\section{Water absorption (WA)}

The WA of the bricks as shown in Table 4, and it is one of the essential mechanical properties of bricks. It depicted the porousness of bricks and it's designated the degree of the reaction of bricks. It was also observing the exact in geo-polymerization bricks temporarily higher degree of geo-polymerization upshots in a less porous and permeable matrix (Ahmari and Zhang 2012).

Outcomes of this study showed that the maximum value (6.56\%) WA recorded in the group and in specimen A1 ratios (09:01, OB: SS) and minimum value (4.32\%) in group B, the specimen B3 (08:02, OB: C). these all of the ratios were under the prescribed Indian standard for the FCB (IS 3495 (Part 2), 1992). The WA of a common FCB value was not more than 20\% (IS 3495 (Part 2), 1992). According to Raheem et al. (2010), the cement steadied interconnecting bricks/blocks were of good quality. Numerous of reports also designated that 
the WA of all the manufacturing bricks at unrelatedly of the firing temperature was less than $20 \%$ (Lamani et al. 2015). A similar study was done by Jamal and Sidharth (2008), discussed in bricks manufacture from OB, the WA (\%) was not more than $10 \%$. In this study, WA varied from 4.32 to $6.56 \%$ and in this regard, it's also shown the quality of manufacturing bricks from $\mathrm{OB}$ was comparatively better than others.

\section{Relation between water absorption and compressive strength}

According to the results of the current study in Figure 3, indicated that the CS increased when WA was decreased in the same way the number of authors also reported the same results (Morchhale et al. 2006). When sodium silicate, as well as cement content, increased than its CS increased and WA decreased (Figure $4 a, b)$ and then a first decision was made that there was a correlation between the CS and WA in both the ratios. The outcomes and fitting equations were shown in Figures $4 a, 4 b$, and equations 1 and 2 respectively.

When the coal mine OB with SS ratio is (09:01 (A1), 17:03 (A2) and 08:02 (A3)),

$Y=-2.2131 X+18.316\left(R^{2}=0.9358\right)$

When the coal mine OB with $\mathrm{C}$ ratio is (09:01 (B1), 17:03 (B2) and 08:02 (B3)).

$Y^{1}=-2.8476 X^{1}+21.319\left(R^{2}=0.947\right)$

Where, $Y$ and $Y^{1}$ are the $C S$ of $O B$ with SS and $C$ ratio of (09:01 (A1), 17:03 (A2) and 08:02 (A3)), and (09:01 (B1), 17:03 (B2) and 08:02 (B3)) respectively.; $X$ and $X^{1}$ were the WA of coal mine $O B$ with sodium silicate and OPC ratio of (09:01 (A1), 17:03 (A2) and 08:02 (A3)), and (09:01 (B1), 17:03 (B2) and 08:02 (B3)) respectively.

As shown in the above-mentioned equation, the correlation coefficients of the fitting curves of coal mine $\mathrm{OB}$ with different sodium silicate and cement ratios were all higher.

The result showed that manufactured bricks with various ratios of binding materials in different ratios observed nil to heavy EFF (Table 5 and Figure $5 a$ ). Only in one of the groups (A), OB, SS and A (A1, A2, and A3) EFF was observed moderate (Fig.5a, Table 5). While nil EFF was observed in the rest of the group (B) of OB: C (B1, B2, and B3) shown in Fig.5b and Table 5. According to IS: 3495 (Part 3), 1992, the EFF to be not more than moderate $(10-50 \%)$ up to class and not more than slight $(<10 \%)$ for higher classes. Veinot et al. (1991) reported that the degree of EFF is greatest for SS and it is also increasing in the humid and $\mathrm{CO}_{2}$ environment (Longhi et al. 2019). EFF also arose due to the reaction between silicate materials and the $\mathrm{CO}_{2}$ in the atmosphere. Some of the scientists tested lithium silicate, potassium silicate, and sodium silicate, and outcome was lithium silicate shown the minimum percentage of EFF comparatively sodium and potassium silicate. Similarly, EFF is too reliant on the silica to metal oxide molar ratio and consequently on the alkalinity of the soluble silicate (Veinot et al. 1991). Zhang et al. (2018) reported the formation of EFF on the surface of the bricks didn't change their mineralogical features. Though, the CS development and compressive modulus of geopolymers may be affected through processes related to the loss of alkalis, and also to sub florescence. The result of EFF (Table 5) depicted that the EFF is heavy when WA is $6.56 \%$ it means it's directly correlated with WA. 
In group $A,(O B: S S)$ three ratios (09:01, 17:03 and 8:02) were manufactured and analysed. A1 bricks fail to fulfil the limit prescribed by Indian standard IS 3495 (Part 3): 1992 w.r.t. EFF (Tables 4 and 5), whereas A2 and A3 bricks fulfil the prescribed limits. Overall A2 was the best bricks in this group because of its economy compared to A3 were heavy to moderate and fulfil the limit prescribed by Indian standard IS 3495 (Part 3): 1992 w.r.t. CS, WA, and EFF whereas sample A1 (9:1) is the best compare to A2 (17:03) and A3 (8:02) (Table 4). Similarly, in group $B,(O B: C)$ three ratios (09:01, 17:03 and 8:02) were developed and analysed. In this group of all the three ratios of bricks manufactured to fulfil to the limit prescribed by IS3495 (Part 3): 1992 w.r.t. CS, WA, and EFF (Table 4). Overall sample B1 is the best in this category because of its economy as compared to sample B2 and B3 (Table 4). Comparing both of the groups B1 is the best bricks due to its economy and full filament the requirement of fire clay bricks IS 1077: 1992 (Reaffirmed 2002).

SEM analysis of the best brick of both of the group found exciting results and its microstructure analysis reveals that a poor interfacial bonds OB and SS bricks (Figure 5a) and a strong interfacial bonding between $\mathrm{OB}$ and $\mathrm{C}$ bricks. A large number of capillary pores seen in Figure $5 \mathrm{a}$ it means manufactured bricks from $\mathrm{OB}$ with SS were not solidified and consolidated completely; its role for higher WA and lower CS (Luo et al. 2020: Mendes et al. 2019) and higher EFF. Furthermore, a large CP observed due to water evaporation and dehydroxylation in the process kilning process in the oven. In fig. $5 \mathrm{~b}$ showed the manufactured brick with OB and cement at optimum temperature 110 $\pm 100 \mathrm{C}$, the degree of melting and consolidation of the bricks was comparatively high in flatted section, its leads to the solid construction. The figure $5 \mathrm{~b}$ showed very small and dispersed capillary pore as well as the cementing of the liquid phase; its help to enhance the CS whereas reducing WA percentage of the bricks (Luo et al. 2020).

\section{Conclusions}

This study indicated that it is possible to use Coal mine overburden to use to manufactured useful bricks and its uses with different binding agent to be used as load bearing and non-load bearing units depending on the heating duration and the proportion of binding agents. This method is measured to be helpful to reutilize the coal mine overburden into useful products and last but not the least the brick (sample B1) will be highly economical compared to common clay bricks (IS 1077: 1992 (Reaffirmed 2002). The manufactured brick has good strength and completely satisfies the requirement of the Bureau of Indian standard code for common burnt clay bricks for construction purposes. Coal mine overburden can be utilized as a brick considering the greater demand of the infrastructure with expanding population. It will not only help to conserve the everincreasing demand for construction material but the brick thus produced will also be energy efficient compared to common clay bricks preparation.

\section{Declarations}

\section{Availability of data and material}

All data generated or analyzed during this study are included in the article.

\section{Competing Interest}

The authors declare they have no competing interests. 


\section{Funding}

This work was supported by CSIR-CIMFR, Barwa Road, Dhanbad-826015, India.

\section{Authors' contributions}

Mr. RK Singh was helpful in acquiring field and laboratory data and in preparing the manuscript

\section{Authors approval}

The co-author have approved to submit the manuscript for publication in Sustainable Environment Research. The authors declare that the manuscript has not been published or submitted for publication elsewhere.

\section{Acknowledgment}

Authors are thankful to Director, CSIR-CIMFR, Barwa Road, Dhanbad, India for his valuable guidance and granting permission to publish this paper

\section{References}

1. Adyel TM, Rahman SH, Islam SMN, Sayem HM, Khan M, Zaman MM (2012) Geo-engineering Potentiality of Electro coagulated Metal Hydroxide Sludge (EMHS) from Textile Industry and EMHS Amended Soil for using as Building Material, International Journal of Current Research. 4(02): 21-25

2. Ahmari S, Zhang L (2012) Production of eco-friendly bricks from copper mine tailing through geopolymerization. Construction and building materials 29; 323-331

3. Anderson JM, Ingram JSI (1992) Tropical soil biology and fertility. A Handbook of methods. ${ }^{\text {nd }}$ Edition. C.A.B. International, p 221.

4. Barapanda P, Singh SK, Pal BK (2001) Utilization of coal mining wastes: An Overview, National Seminar on Environmental Issues and Waste Management in Mining and Allied Industries, Regional Engg College, Rourkela, Orissa, India. 177- 182.

5. Behera SK, Ghosh CN, Mishra DP, Singh P, Mishra K, Buragohain (2020) Strength development and microstructural investigation of lead-zinc mill tailingsbased paste backfill with fly ash as alternative binder. Cement and concrete composites, https://doi.org/10.1016/j.cemconcomp.2020.103553.

6. Bhaskar M, Akhtar S, Batham G (2014) Development of the Bricks from Red Mud by Industrial waste (Red Mud). International Journal of Emerging science and engineering (IJESE), 2(4): 7-12.

7. Bowles E (2012) Engineering Properties of Soils and their Measurements, $4^{\text {th }}$ edition, McGraw Hill Education (India) Private Limited, New Delhi.

8. Chen Y, Zhang Y, Chen T, Zhao Y, Bao S (2011) Preparation of eco-friendly construction bricks from hematite tailings. Construction and building materials 25: 2107-2111.

9. Du Q, Pan T, Lv J, Zhou J, Ma Q, Sun Q (2019) Mechanical properties of sandstone cement -stabilized macadam. Applied sciences. doi:10.3390/app9173460

10. Food and agriculture organization of United Nations (2020). Retrieved on 07/01/2020, fromhttp://www.fao.org/tempref/FI/CDrom/FAO_Training/FAO_Training/General/x6706e/x6706e06.htm 
11. Gupta PK (2004) Methods in environmental analysis: Water, soil and water. Agrobios, Jodhpur, India.

12. Harrison DJ, Blood worth AJ, Eyre JM, Mitchell MCJ, Scot PW, Steadman JM (2002) Utilization of mineral waste: case studies, BGS commission report CR/02/227 N.

13. Hossiney N, Das P, Mohan MK, George J (2018) In-plant production of bricks containing waste foundry sand-A study with Belgaum foundry industry. Case Studies in Construction Materials, doi:10.1016/j.cscm.2018.e00170

14. http://environmentclearance.nic.in/writereaddata/EIA/1111291220121211129-2007.pdf. Accessed 22 July 2020.

15. http://www.ce.memphis.edu/1101/notes/concrete/PCA_manual/Chap05.pdf Accessed 22 July 2020.

16. https://coal.nic.in/sites/upload_files/coal/files/coalupload/coaldir11-12.pdf Accessed at 17 July 2020

17. https://www.power-technology.com/features/top-five-coal-producing-countries-world/ Accessed 17 July 2020

18. https://www.worldcoal.org/coal/coal-

mining\#: :text=Sign\%20up\%20now-,Coal\%20mining,'\%20mining\%2C\%20and\%20underground\%20mining. Accessed at 17 July 2020

19. ICMOS (2019). Proceedings of ( $2^{\text {nd }}$ International conference on opencast mining technology and sustainability), organized by Northern coalfield limited, Singrauli between $13^{\text {th }}$ to $14^{\text {th }}$ December 2019. http://nclcil.in/ICOMS/ICOMS-2019\%20Souvenir.pdf

20. Indian Standard (IS): 3495 (Part 1) (1992). Methods of tests of Burnt Clay Building Bricks, Part 1 Determination of compressive strength (third Edition), Bureau of Indian Standards, New Delhi.

21. Indian Standard (IS): 3495 (Part 2) (1992). Methods of tests of Burnt Clay Building Bricks, Part 2 Determination of Water absorption (third Edition), Bureau of Indian Standards, New Delhi.

22. Indian Standard (IS): 3495 (Part 3) (1992). Methods of tests of Burnt Clay Building Bricks, Part 3 Determination of Determination of efflorescence (third Edition), Bureau of Indian Standards, New Delhi.

23. Indian Standard (IS: 1122-1974) Reaffirmed 2003. Method of test for determination of true specific gravity of natural building stones (first revision). Third reprint April 1988.

24. Islam SM, Hashim R, Saiful Islam ABM, Kurnia R (2014) Effect of peat on physicomechanical properties of cemented brick. Scientific world journal doi:10.1155/2014/328516.

25. Jamal A, Siddharth S (2008) Value added constructional bricks from overburden of opencast coalmines. Journal of scientific and industrial research 67: 445-450.

26. Lamani SR, Aruna M, Vardhan H, Shanth AT (2015) Development of value-added product using iron ore waste for tis effective utilization. International Journal of Advanced and Applied Sciences 2 (12): 30-35.

27. Longhi MA, Zhang Z, Rodriguez ED, Kirchheim AP, Wang H (2019) efflorescence of Alkali- Activated Cement (Geopolymers) and the Impacts on Material structures: A critical analysis. Frontiers in Materials, hypothesis and theory.https://doi.org/10.3389/fmats.2019.00089

28. Luo L, Li K, Fu W, Liu C, Yang S (2020) Preparation, characteristics and mechanisms of the composite sintered bricks produced from shale, sewage sludge, coal gangue powder and iron ore tailings. Construction and building materials. https://doi.org/10.1016/j.conbuildmat.2019.117250. 
29. Lv J, Zhou TH, Du Q, Wu HH, (2015) Effects of rubber particles on mechanical properties of lightweight aggregate concrete. Construction and building materials91, 145-149.

30. Malhotra S K, Tehri S P (1996) Development of bricks from granulated blast furnace slag. Construction and Building Materials, 10(3): 191-193.

31. Mendes BC, Pedroti LG, Fontes MPF, Ribeiro JCL, Vieira CMF, Pacheco AA, Azevedo ARGD (2019) Technical and environmental assessment of the incorporation of iron ore tailings in construction clay bricks. Construction and building materials, https://doi.org/10.1016/j.conbuildmat.2019.08.050

32. Mishra R. (1968) Ecology Workbook. Oxford and IBH Publishing Co., Calcutta. p. 244

33. Morchhale R K, Ramakrishnan N, Dindorkar N (2006) Bulk utilisation of copper mine tailings in production of bricks. Journal of the Institution of Engineers. India. Civil Engineering Division, 87:13-16.

34. Nagaraj HB, Sravan MV, Arun TG, Jagadish KS (2014) Role of lime with cement in long- term strength of compressed stabilized earth blocks. International journal of sustainable built environment 3 (1): 54-61.

35. Pandey PK, Agrawal RK (2002) Utilization of mixed pond ash integrated steel plant for manufacturing superior quality bricks, Bull Matter sci, 25: 443-447.

36. Pinheiro M, Vieira CMF, Sánchez RJ, Monteiro SN (2008) Recycling of waste from paper production in red ceramic. Rev. Mater. 13: 220-227.

37. Raheem AA, Bello OA, Makinde OA (2010) A comparative study of cement and lime stabilized lateritic interlocking blocks. The Pacific journal of science and technology. 11: 27-34.

38. Raj PP (2017) Building construction materials and techniques.Pearson education India. 624. ISBN 978-93325-4479-6, elSBN 978-93-325-7882-1.

39. Rana A, Kalla P, Csetenyi LJ (2015) Sustainable use of marble slurry in concrete. Journal of cleaner production. 94: 304-311

40. Rathore AS, Pradhan M, Deo SV (2020) Evaluation of Coal Mine Overburden Clay for Assessing Its Suitability for Brick Making. International Journal of Applied Environmental Sciences, 1: 63-75.

41. Reddy VBV (2004) Sustainable building technologies, current science87: 899-907.

42. Reddy VBV, Sudhakar MR, Kumar A (2003) Characteristics of stabilized mud blocks using ash modified soil, Indian concrete journal77:903-911.

43. Roy S, Adhikari GR, Gupta RN (2007) Use of gold mill tailings in making bricks: a feasibility study. Waste Management \& Research 25(5): 475-482

44. Sharma P, Joshi H (2015) Utilization of electrocoagulation-treated spent wash sludge in making building blocks. International Journal of Environmental Science and Technology 13(1): 349-358.

doi:10.1007/s13762-015-0845-7

45. Singh RK, Singha M, Singh SK, Pal D, Tripathi N, Singh RS (2018) Land use/ Land cover change detection analysis using remote sensing and GIS of Dhanbad district, India. 6 (2): 1-12.

46. Singh S, Khan S, Khandelwal R, Chugh A, Nagar R (2016) Performance of sustainable concrete containing granite cutting waste. Journal of cleaner production. 119: 86-98

47. Tripathi N, Hills CD, Singh RS, Carey, PJ (2017) Construction: use waste for building. Nature (London) 550: 457. 
48. Tripathi N, Singh RS, Hills C D (2016) Reclamation of Mine-impacted Land for Ecosystem Recovery.John Wiley \& Sons.

49. Vakalova TV, Revva IB (2020) Use of zeolite rocks for ceramic bricks based on brick clay and clay loams with high drying sensitivity. Construction and building materials.https://doi.org/10.1016/j.conbuildmat.2020.119324

\section{Tables}

Table 1 Sieve analysis data of coal mine overburden

\begin{tabular}{|c|c|c|c|c|c|}
\hline $\begin{array}{l}\text { Type of } \\
\text { soil }\end{array}$ & $\begin{array}{l}\text { Sieve Size } \\
(\mathrm{mm})\end{array}$ & $\begin{array}{l}\text { Weight retain on each } \\
\text { sieve(gram) }\end{array}$ & $\begin{array}{l}\text { Weight retain on each } \\
\text { sieve (\%) }\end{array}$ & Cumulative & $\begin{array}{l}\text { Finer } \\
(\%)\end{array}$ \\
\hline \multirow{2}{*}{$\begin{array}{l}\text { Coarse } \\
\text { sand }\end{array}$} & 4.75 & 3.21 & 0.536 & 0.536 & 99.464 \\
\hline & 2.00 & 6.95 & 1.194 & 1.73 & 98.27 \\
\hline $\begin{array}{l}\text { Medium } \\
\text { sand }\end{array}$ & 0.425 & 444.66 & 76.399 & 78.129 & 21.871 \\
\hline Fine sand & 0.075 & 117.17 & 20.131 & 98.26 & 1.74 \\
\hline $\begin{array}{l}\text { Silt and } \\
\text { clay }\end{array}$ & $\begin{array}{l}\text { Passing } \\
0.075\end{array}$ & 10.12 & 1.738 & 99.998 & 0.002 \\
\hline
\end{tabular}

Table 2 Physical properties of of coal mine overburden

\begin{tabular}{|llllll|}
\hline Property & $\begin{array}{l}\text { Specific } \\
\text { gravity }\end{array}$ & $\begin{array}{l}\text { Bulk Density } \\
\left(\mathbf{g} / \mathrm{cm}^{3}\right)\end{array}$ & $\begin{array}{l}\text { Porosity } \\
(\%)\end{array}$ & $\begin{array}{l}\text { Fineness } \\
\text { modulus }\end{array}$ & $\begin{array}{l}\text { Moisture content } \\
(\%)\end{array}$ \\
\hline Composition & 2.22 & 1.30 & 25 & 2.79 & $7.01 \%$ \\
\hline
\end{tabular}

Table 3 Chemical composition (\%) of of coal mine overburden and cement

\begin{tabular}{|lccccccccccc|}
\hline Composition & $\mathrm{SiO}_{2}$ & $\mathrm{Al}_{2} \mathrm{O}_{3}$ & $\mathrm{Fe}_{2} \mathrm{O}_{3}$ & $\mathrm{CaO}$ & $\mathrm{MgO}$ & $\mathrm{TiO}_{2}$ & $\mathrm{~K}_{2} \mathrm{O}$ & $\mathrm{Na}_{2} \mathrm{O}$ & $\mathrm{P}_{2} \mathrm{O}_{5}$ & $\mathrm{SO}_{3}$ & Lol \\
\hline $\begin{array}{l}\text { Coal Mine } \\
\text { OB (\%) }\end{array}$ & 58.86 & 29.09 & 4.17 & 1.21 & 0.81 & 1.76 & 3.44 & 0.11 & 0.08 & 0.47 & 6.57 \\
$\begin{array}{l}\text { Cement (C) } \\
(\%)\end{array}$ & 24.98 & 4.84 & 3.02 & 61.24 & 1.42 & 0.48 & 0.39 & 0.29 & 0.8 & 2.5 & 0.07 \\
\hline
\end{tabular}

Table 4 Compressive strength, water absorption and bulk density, efflorescence and cost wise ranking of manufactured bricks 


\begin{tabular}{|c|c|c|c|c|c|c|}
\hline $\begin{array}{l}\text { Sample } \\
\text { ID } \\
\text { (SID) }\end{array}$ & $\begin{array}{l}\text { Mixing } \\
\text { ratios }\end{array}$ & $\begin{array}{l}\text { Water } \\
\text { Absorption } \\
\text { (WA) (\%) }\end{array}$ & $\begin{array}{l}\text { Compressive } \\
\text { Strength (CS) } \\
\left(\mathrm{N} / \mathrm{mm}^{2}\right)\end{array}$ & $\begin{array}{l}\text { Heating } \\
\text { Duration } \\
\text { (hr) }\end{array}$ & $\begin{array}{l}\text { Efflorescence } \\
(\mathrm{EFF})\end{array}$ & $\begin{array}{l}\text { Cost wise } \\
\text { ranking (within } \\
\text { category) }\end{array}$ \\
\hline \multicolumn{7}{|c|}{ (A) OB: sodium silicate } \\
\hline A1 & 09:01 & 6.56 & 4.2 & 18 & Heavy & 1 \\
\hline A2 & 17:03 & 5.60 & 5.2 & 18 & Moderate & 2 \\
\hline A3 & 08:02 & 4.40 & 8.9 & 18 & Moderate & 3 \\
\hline \multicolumn{7}{|c|}{ (B) OB: cement } \\
\hline B1 & 09:01 & 5.88 & 4.7 & 18 & Nil & 1 \\
\hline B2 & $17: 03$ & 4.64 & 7.5 & 18 & Nil & 2 \\
\hline B3 & 08:02 & 4.48 & 9.5 & 18 & Nil & 3 \\
\hline $\begin{array}{l}\text { FCB } \\
\text { (IS 1077: }\end{array}$ & 992) & $=<20$ & 3.50 & - & - & \\
\hline
\end{tabular}

Table 5. Efflorescence of manufactured bricks

\begin{tabular}{|lllll|}
\hline $\begin{array}{l}\text { Sample } \\
\text { ID }\end{array}$ & $\begin{array}{l}\text { Total Area of Bricks } \\
\left(\mathrm{cm}^{2}\right)\end{array}$ & $\begin{array}{l}\text { Efflorescence area } \\
\left(\mathrm{cm}^{2}\right)\end{array}$ & $\begin{array}{l}\text { Efflorescence } \\
(\%)\end{array}$ & $\begin{array}{l}\text { Status (IS: 3495-(Part 3) } \\
(1992) .\end{array}$ \\
\hline A1 & 1673 & 689 & 51.18 & Heavy \\
\hline A2 & 1673 & 472 & 28.21 & Moderate \\
\hline A3 & 1673 & 290 & 17.33 & Moderate \\
\hline B1 & 1673 & 0 & 0 & Nil \\
\hline B2 & 1673 & 0 & 0 & Nil \\
\hline B3 & 1673 & 0 & 0 & Nil \\
\hline
\end{tabular}

\section{Figures}




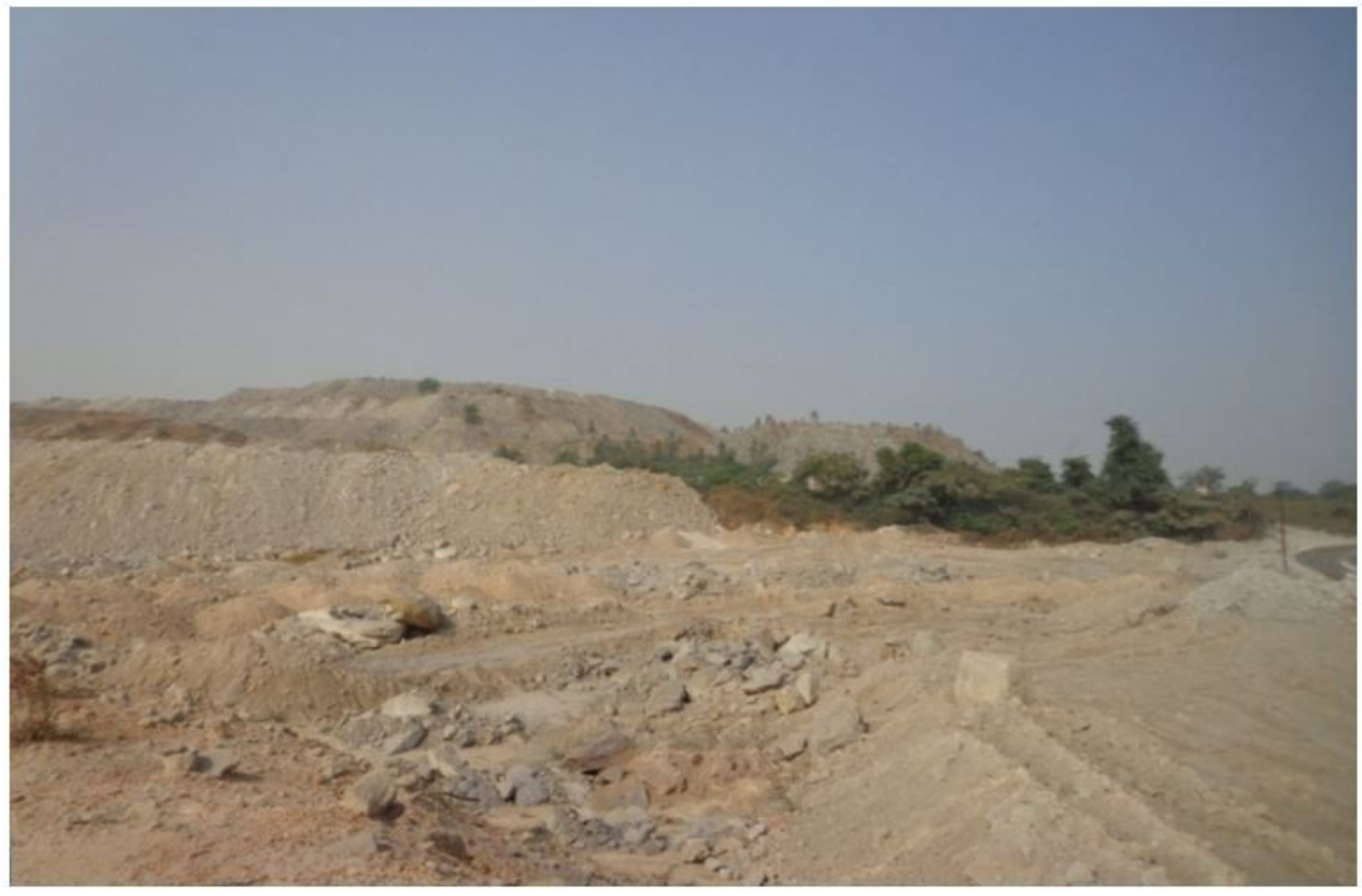

Figure 1

View of waste dumps in Manikpur OCP 


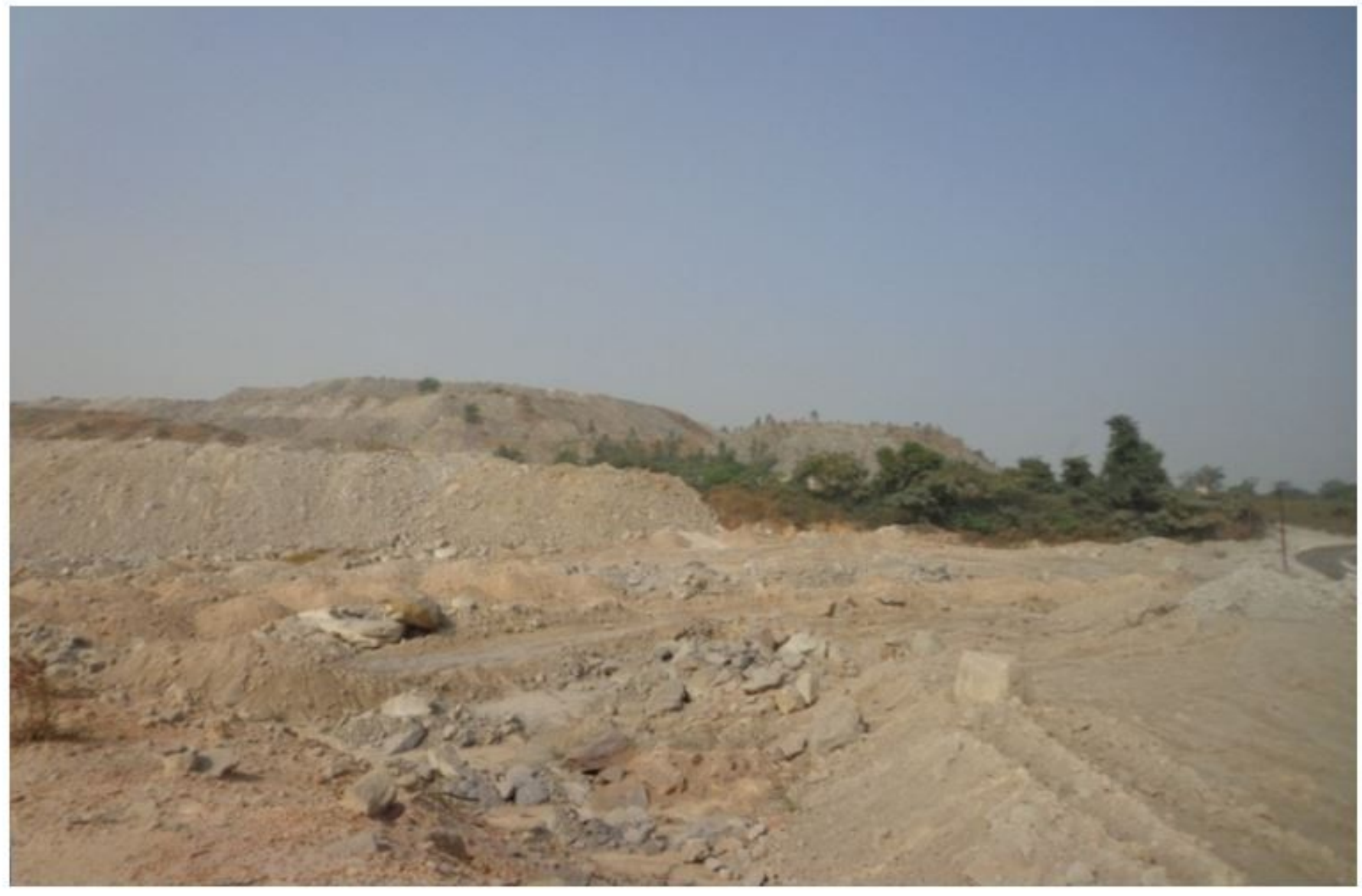

Figure 1

View of waste dumps in Manikpur OCP 


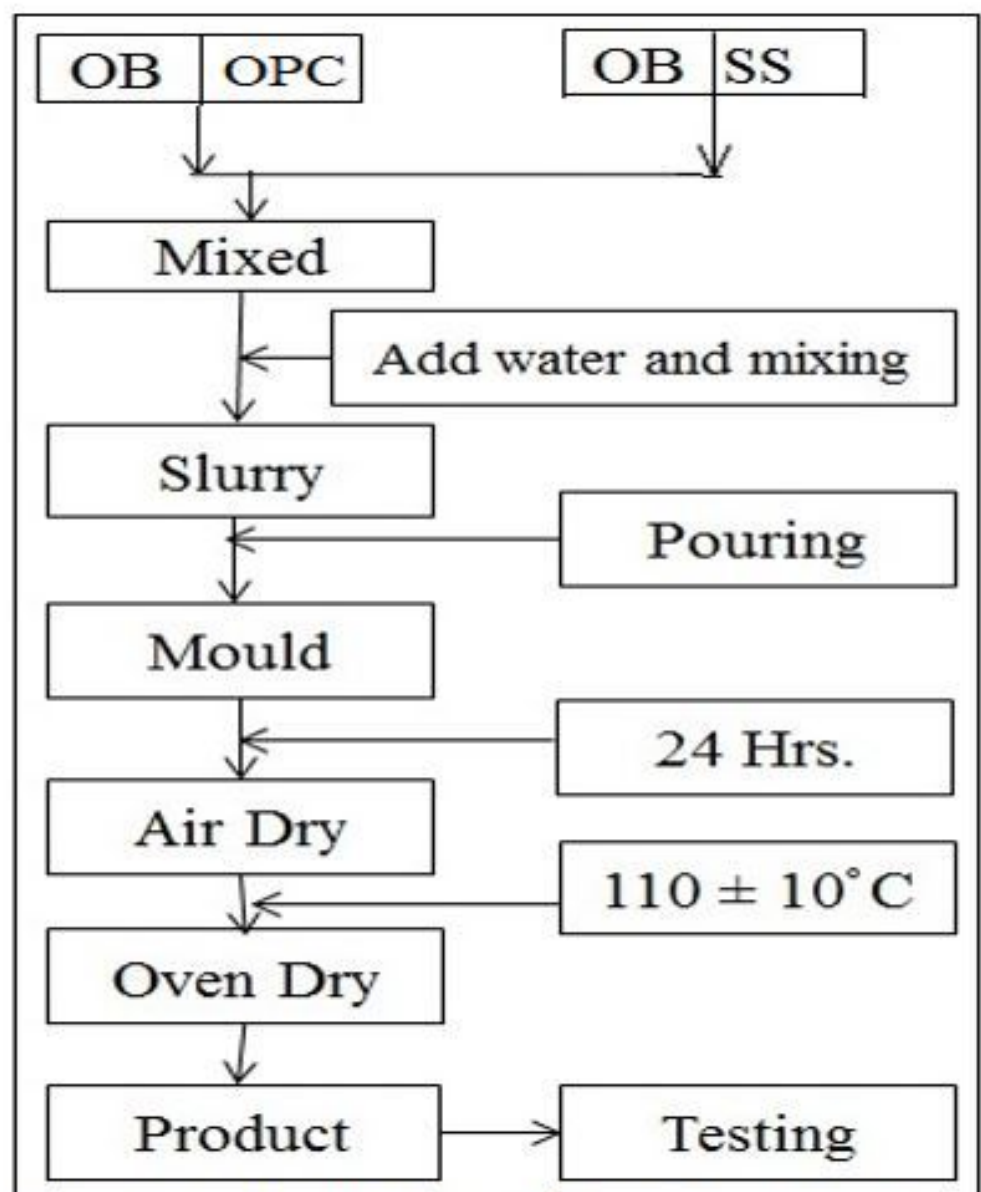

OB-Overburden, OPC-Cement, SS-Dodium silicate

Figure 2

Flow charts of of manufactured bricks process 


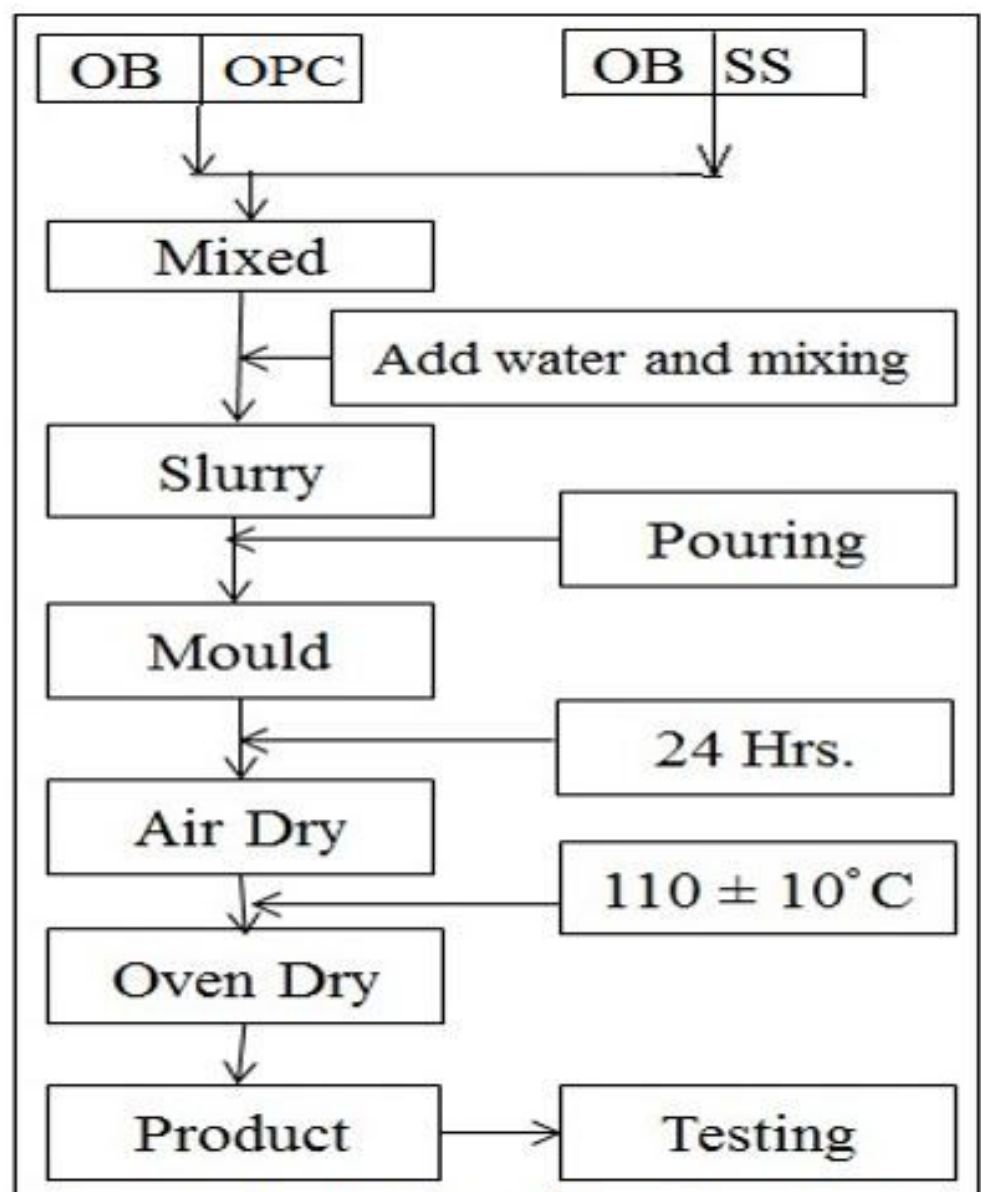

OB-Overburden, OPC-Cement, SS-Dodium silicate

Figure 2

Flow charts of of manufactured bricks process 


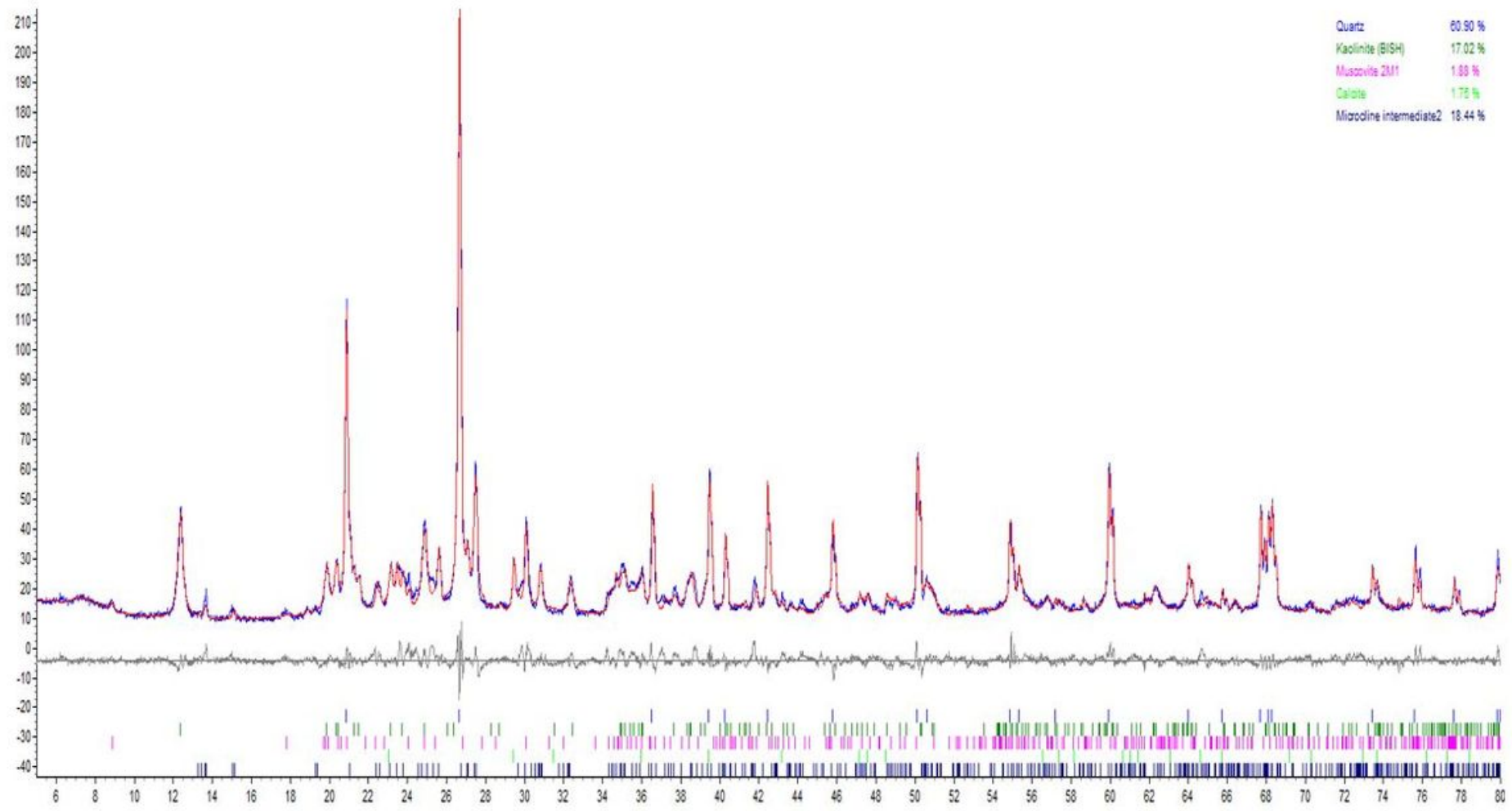

Figure 3

XRD pattern of Coal Mine OB

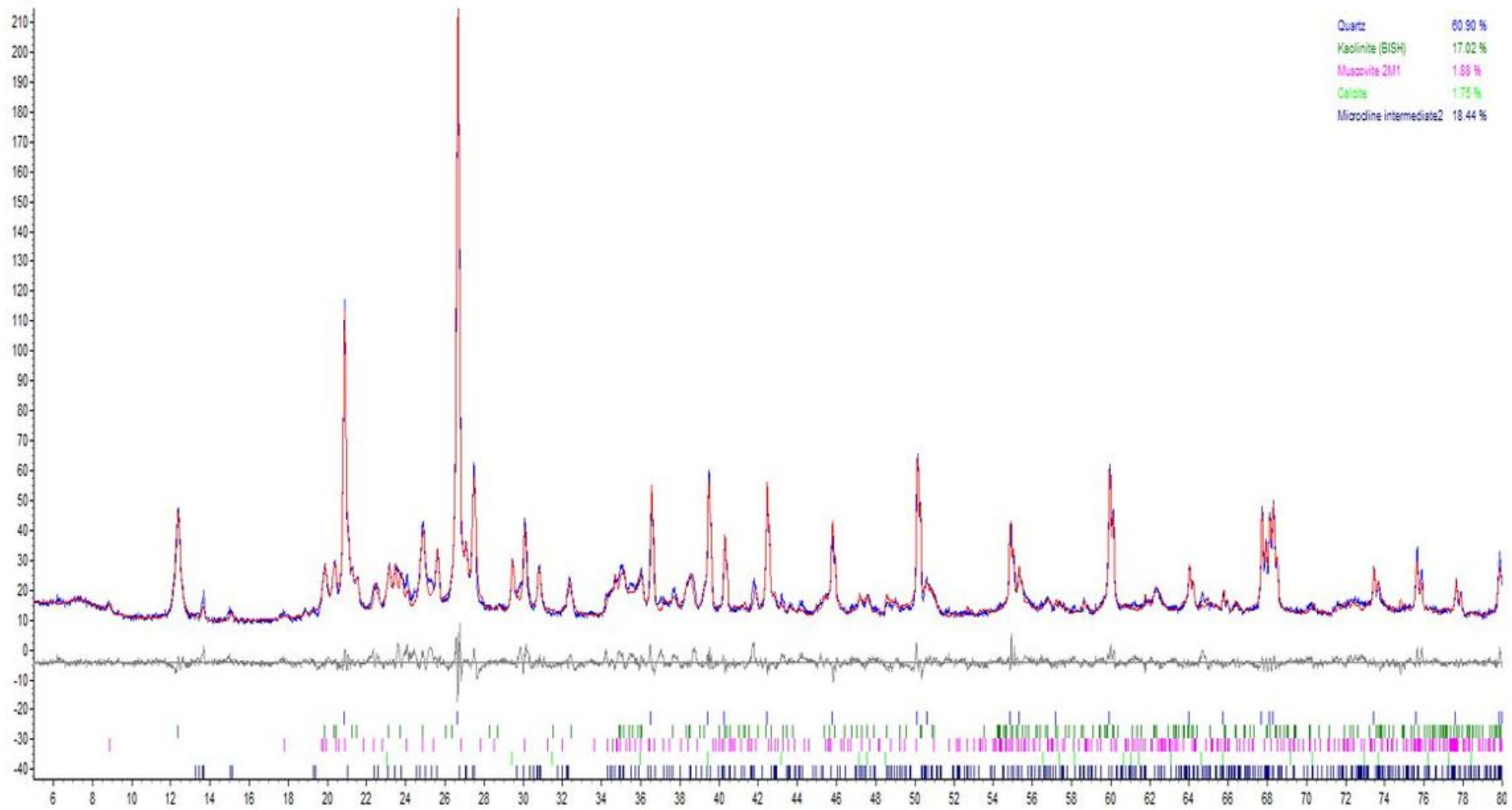

Figure 3 


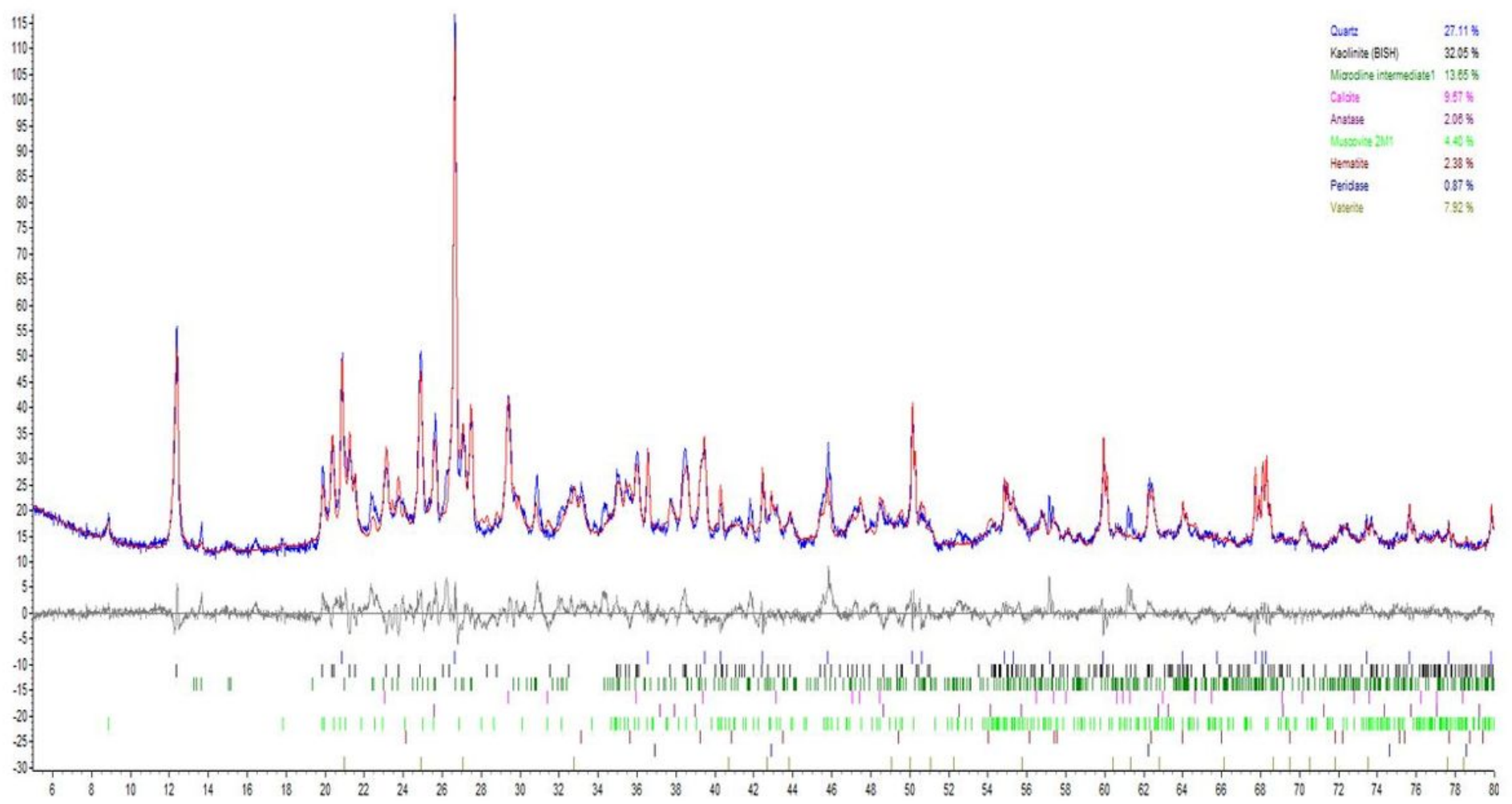

\section{Figure 4}

XRD pattern of manufactured bricks from Coal Mine OB with cement

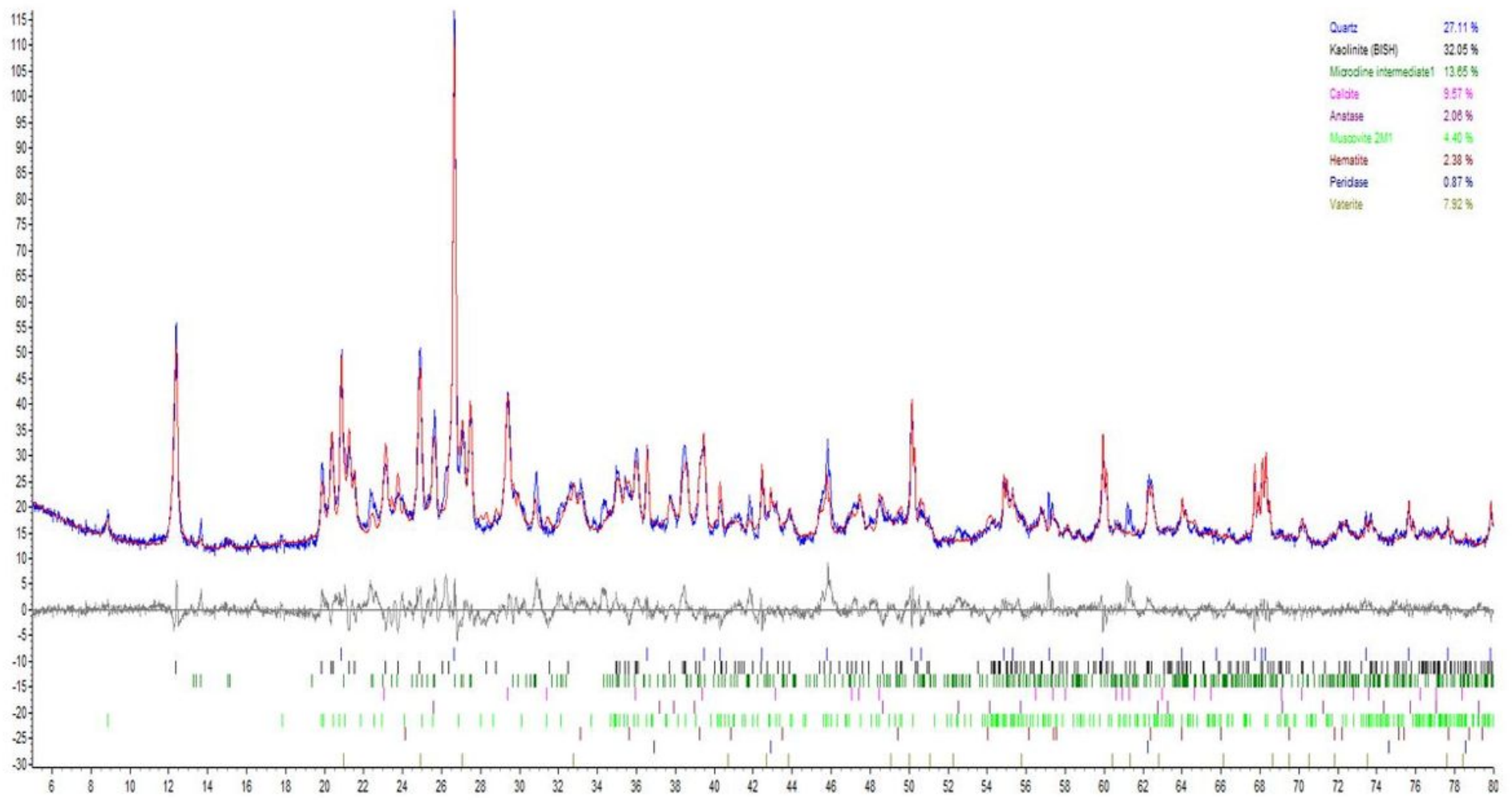


Figure 4

XRD pattern of manufactured bricks from Coal Mine OB with cement

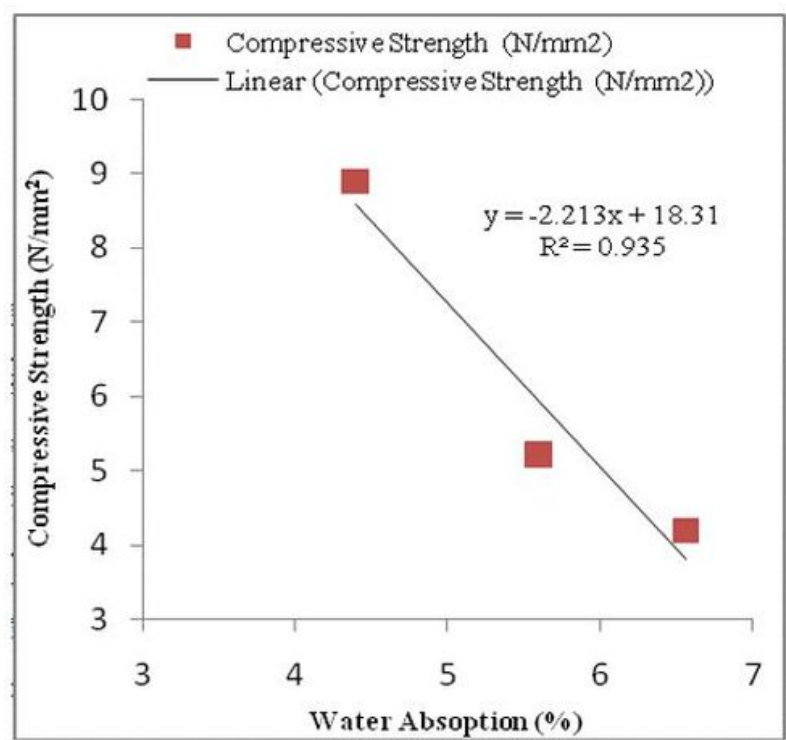

(a) Coal mine overburden: sodium silicate

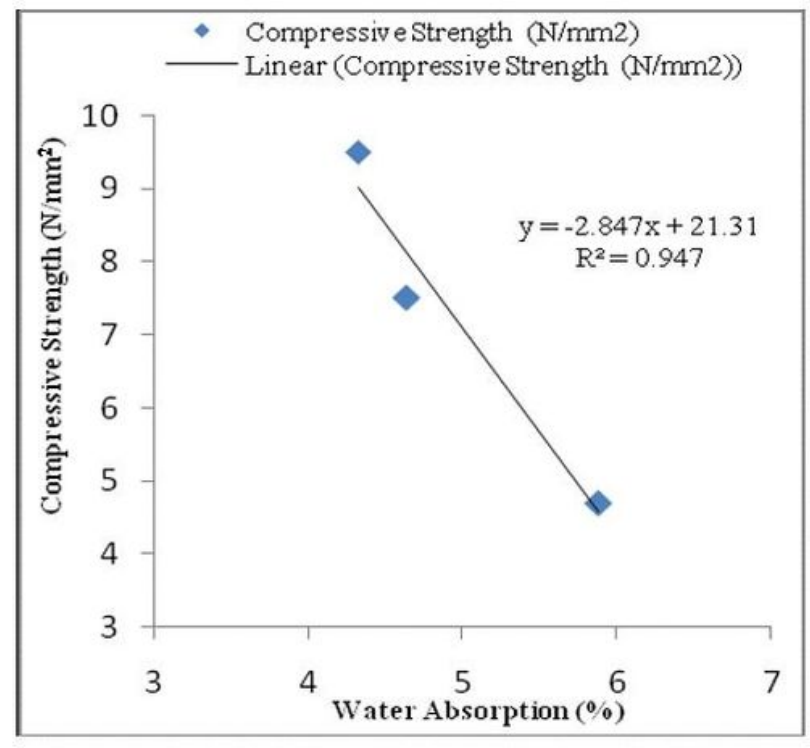

(b) Coal mine overburden: cement

Figure 5

Relationship between Water absorption (\%) and compressive strength (N/mm2)

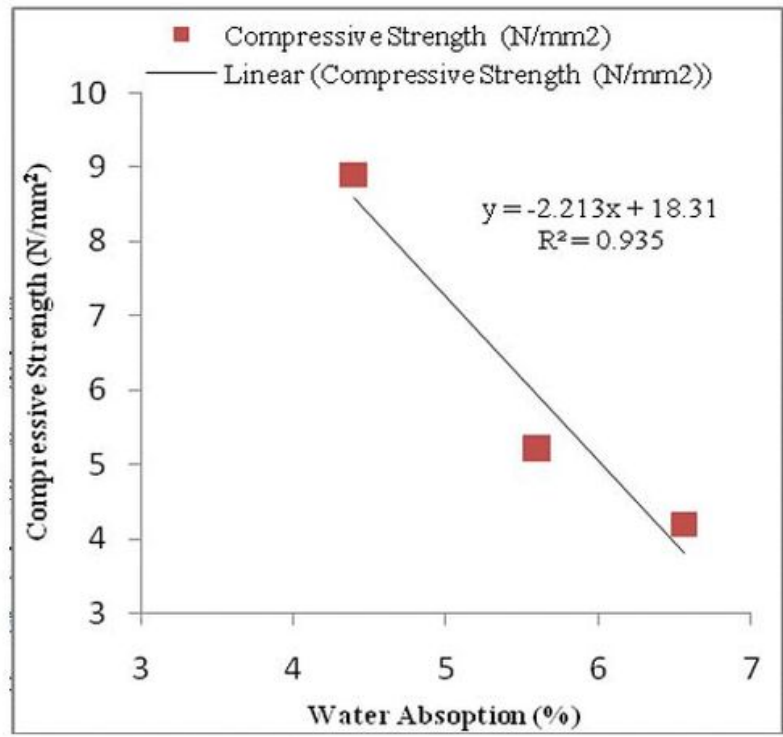

(a) Coal mine overburden: sodium silicate

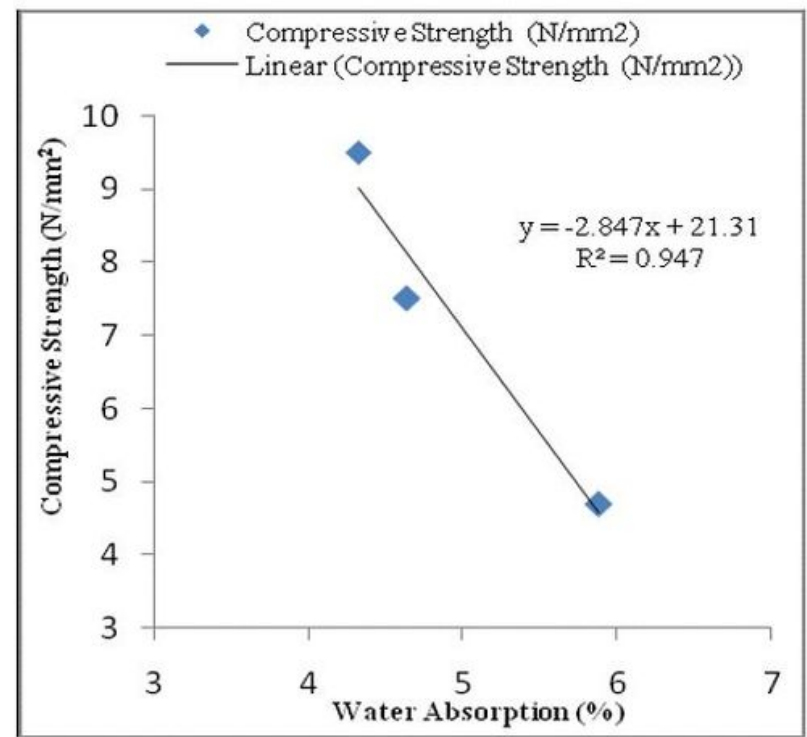

(b) Coal mine overburden: cement

\section{Figure 5}

Relationship between Water absorption (\%) and compressive strength (N/mm2) 

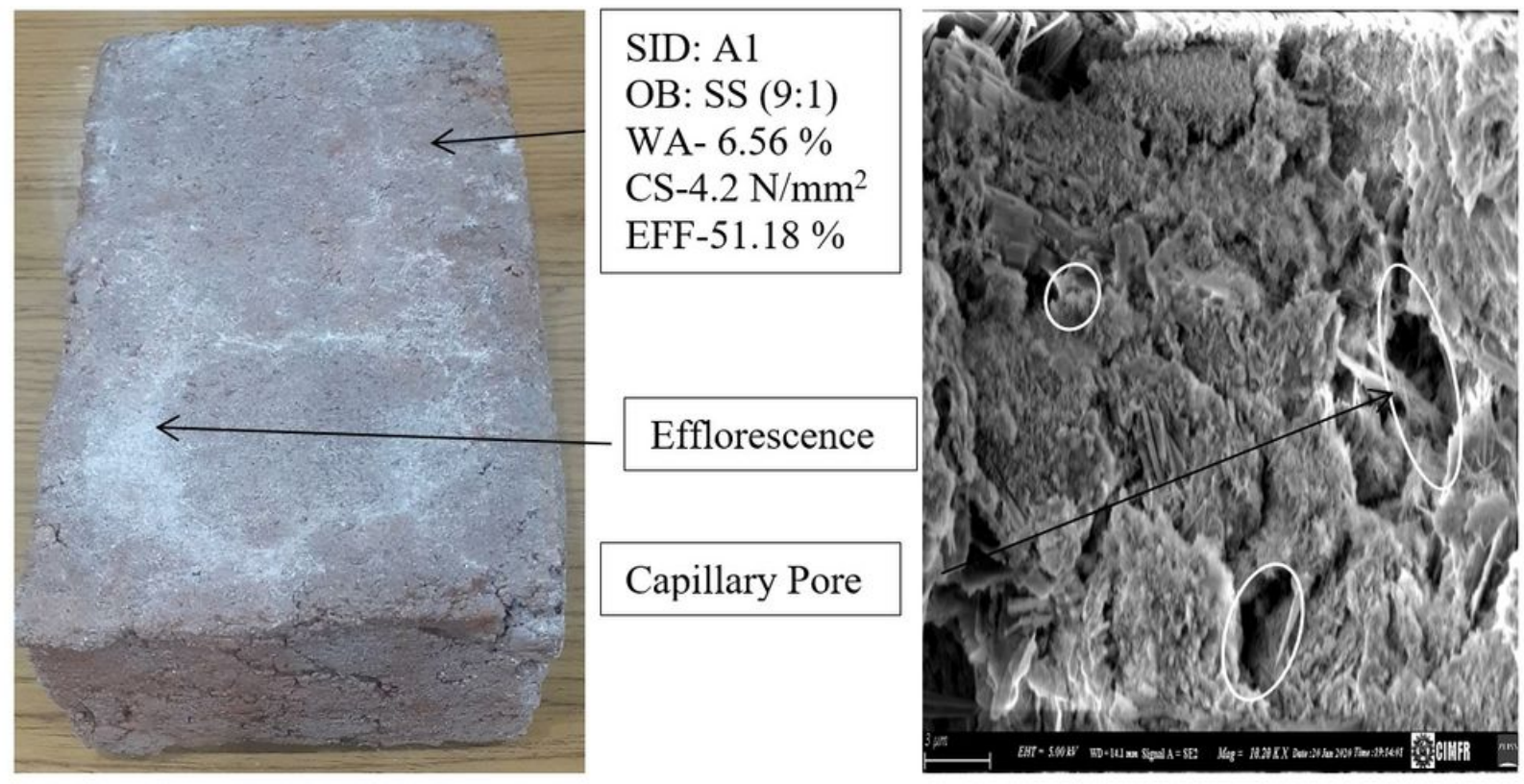

(a). Coal mine overburden: sodium silicate
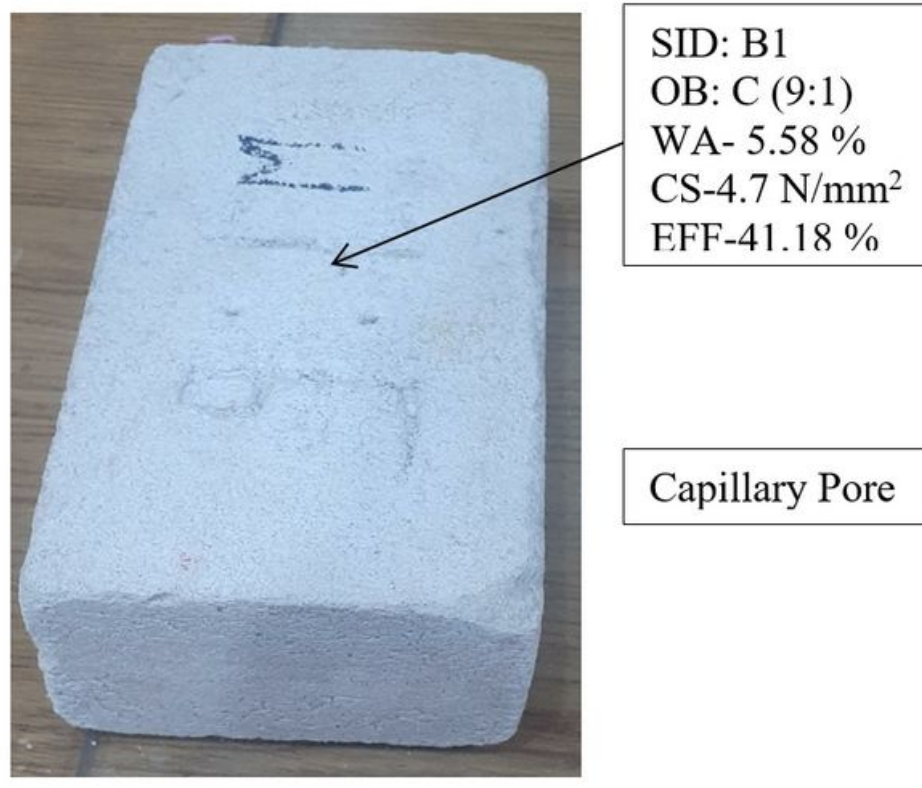

(b). Coal mine overburden: cement

\section{Figure 6}

Best bricks in both the groups showing with efflorescence with microstructure analysis by SEM 


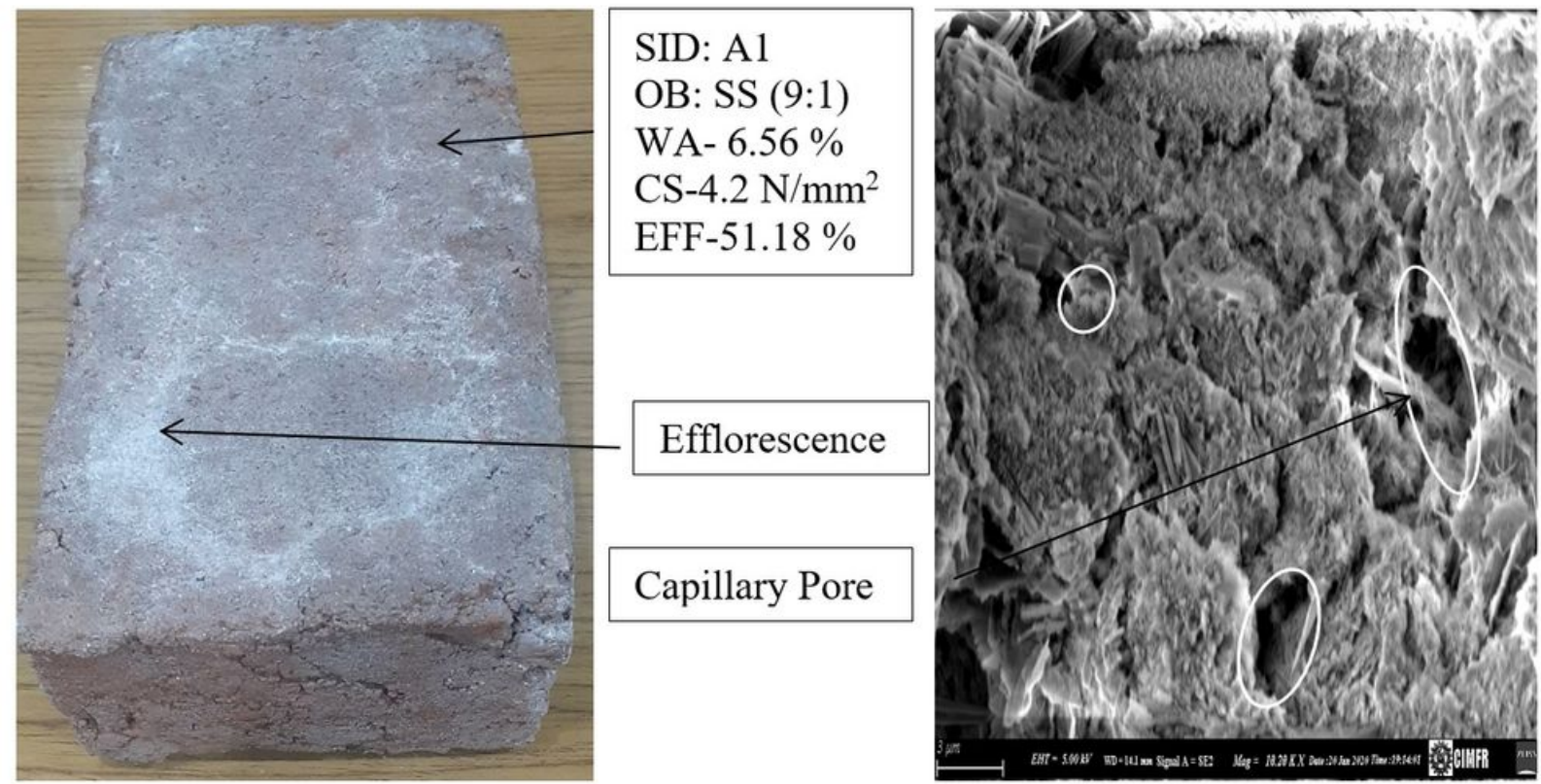

(a). Coal mine overburden: sodium silicate
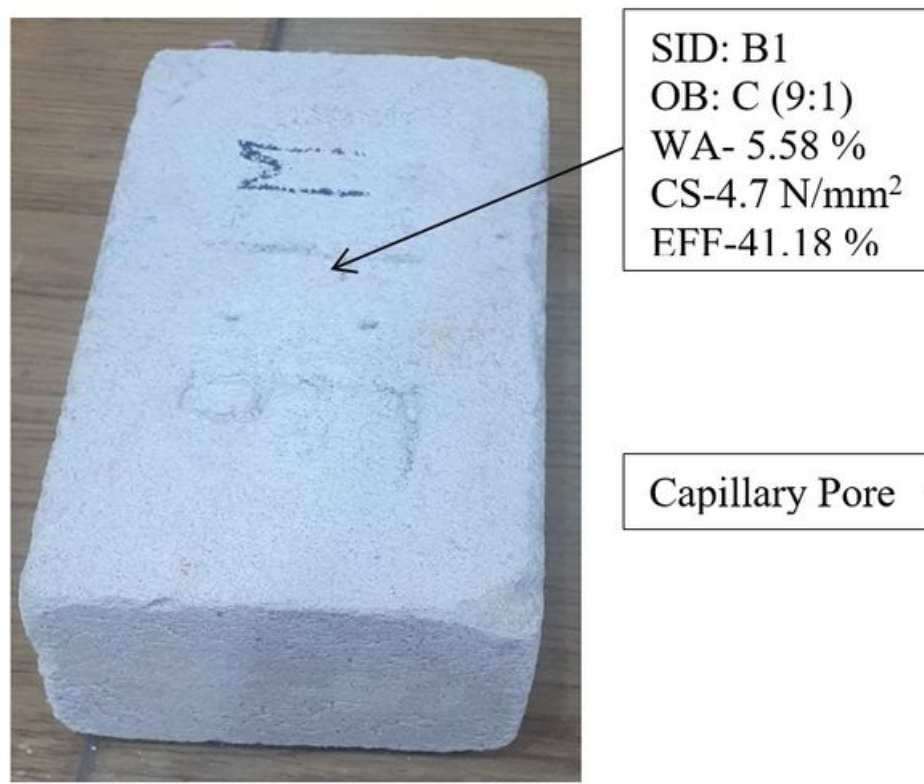

(b). Coal mine overburden: cement

\section{Figure 6}

Best bricks in both the groups showing with efflorescence with microstructure analysis by SEM 